\section{Morphological Study and Analysis of Microhardness and Permeability of the Furcation of Maxillary Premolars}

\author{
Tiago Elias Nascimento, Luis Eduardo Souza-Flamini, Regina Guenka Palma- \\ Dibb, Ricardo Gariba Silva, Paulo Cesar Saquy, Jesus Djalma Pécora, Antonio \\ Miranda Cruz-Filho
}

Department of Restorative Dentistry, Dental School of Ribeirão Preto, USP - Universidade de São Paulo, Ribeirão Preto, SP, Brazi

Correspondence: Prof. Dr. Antonio M. Cruz-Filho, Avenida do Café, s/n, 14040-904 Ribeirão Preto, SP, Brasil. Tel: +55-16-33154792. e-mail: cruz@forp.usp.br

\begin{abstract}
The morphology, microhardness and dentin permeability of the furcation region of maxillary premolars were evaluated. Ten premolars were cut lengthwise and the furcation region was delimited. In one group $(n=10)$ microhardness was measured in the buccal, central and palatal regions, in the outer middle and inner layers of the furcation, and in the buccal and palatal regions adjacent to the furcation. Knoop hardness was tested with $10 \mathrm{~g}$ load for $15 \mathrm{~s}$. Data were analyzed statistically by ANOVA and Tukey-Kramer test $(\alpha=0.05)$. In the other group $(n=10)$ confocal microscopy was used to study dentin morphology. Other 10 specimens were instrumented with ProTaper and immersed in 10\% copper sulfate for analysis of permeability under light microscopy. About microhardness, there was no significant difference ( $p>0.05)$ among the buccal $(39.9 \pm 3.1)$, central $(39.5 \pm 4.4)$ and palatal $(39.7 \pm 5.0)$ regions of the furcation, or between these regions and the adjacent buccal $(39.1 \pm 5.8)$ and palatal $(39.7 \pm 5.8)$ regions $(p>0.05)$. The inner layer $(42.3 \pm 3.7)$ had significantly higher microhardness $(p<0.05)$ than the outer layer $(37.1 \pm 3.9)$. There was a tendency of calcification of the dentinal tubules from the outer towards the inner layer. The percentage of stained area was $12.45 \pm 2.0 \%$, restricted to the outer layer. The buccal, central and palatal regions of the furcation as well as the buccal and palatal adjacent regions had similar microhardness values. In conclusion, the inner dentin layer is harder than the outer dentin layer. The dentinal tubules are sinuous and intertwine towards the middle layer. Dye penetration is restricted to the outer layer.
\end{abstract}

Key Words: dentin microhardness, furcation, maxillary premolar, permeability.

\section{Introduction}

The physical and morphological characteristics of the coronal and radicular dentin tissue have been evaluated in different human dental groups $(1,2)$. Despite the relevance of the subject, little attention was given to the dentin in the furcation area. Furcation is considered as the area or region located between two or more roots, anatomically and usually divided at its base (3). Restricted information about the dental furcation region reveals that, in mandibular molars, the microhardness of this area is uniform across its mesial, central and distal axes (4). As also reported that the dentinal tubules have a centripetal trajectory of the pulp chamber floor towards the bifurcation of the roots (4). A previous study showed that the furcation of mandibular molars is constituted, in a large part, by amorphous and less tubular dentin than the primary, being highly resistant to the penetration of fluids (5). Based on these studies, it may be suggested that dentin morphology in the furcation area has specific characteristics different from the other areas.

The morphological study of dentin in premolars has basically addressed the density of the dentinal tubules by the dentin surface (6). For this purpose, various methodologies are suggested: the histochemical method
(5), microscopic immunofluorescence (7), different types of light microscopy, such as polarized (8), phase contrast and interference microscopy (9), transmission electron microscopy (10), microradiography (11), fluids movement (12) and scanning electron microscopy (SEM) (13). Recent studies have used confocal laser scanning microscopy to observe very clearly the dentinal tubules. This method proved to be more advantageous than the SEM and other methodologies $(14,15)$.

The internal and external anatomy of maxillary premolars has been extensively investigated. However, no study was found on the morphology and physical proprieties of dentin at the furcation area in these teeth. For these reasons, the aim of this study was to evaluate by confocal microscopy, the dentin morphology at the furcation of maxillary premolars with divergent roots and to analyze dentin microhardness and permeability of this region.

\section{Material and Methods}

Specimen Preparation

After approval by the Research Ethics Committee of the Dental School of Ribeirão Preto, were selected 20 maxillary 
premolars with divergent roots. Half the specimens $(n=10)$ were intended for the analysis of microhardness and morphological study of the dentin and the other half $(n=10)$ for the analysis of permeability. The specimens were stored in a $0.1 \%$ thymol solution until use, when they were rinsed in running water for $24 \mathrm{~h}$.

Initially, ten teeth were inserted into silicone molds, including rapid polymerization of acrylic and taken to a hard-tissue cutting machine. Two transversal cuts were performed, the first in the middle portion of the anatomical crown, discarding the occlusal portion. The second, directed to the buccal and palatal roots, in the cervical third near the root bifurcation. The root portions of the middle and apical thirds were discarded. A third cut was performed along the axis of the tooth, towards the buccal-palatal. Thus, two hemisections were obtained, one intended for the analysis of the microhardness and the other to study the dentin morphology. Each hemisection was sanded under running water and polished with felt discs. During this phase, a $40 \times$ magnifying glass was used as a visual aid for confirmation of dentin smoothness.

\section{Analysis of Dentin Microhardness}

The delimitation of the furcation area was based on the methodology used by Pécora et al. (4). Initially, it determined the point on the outer surface of the most concave part of the furcation (C). From that point, two straight orthogonal lines were traced using a scalpel blade, extending to the
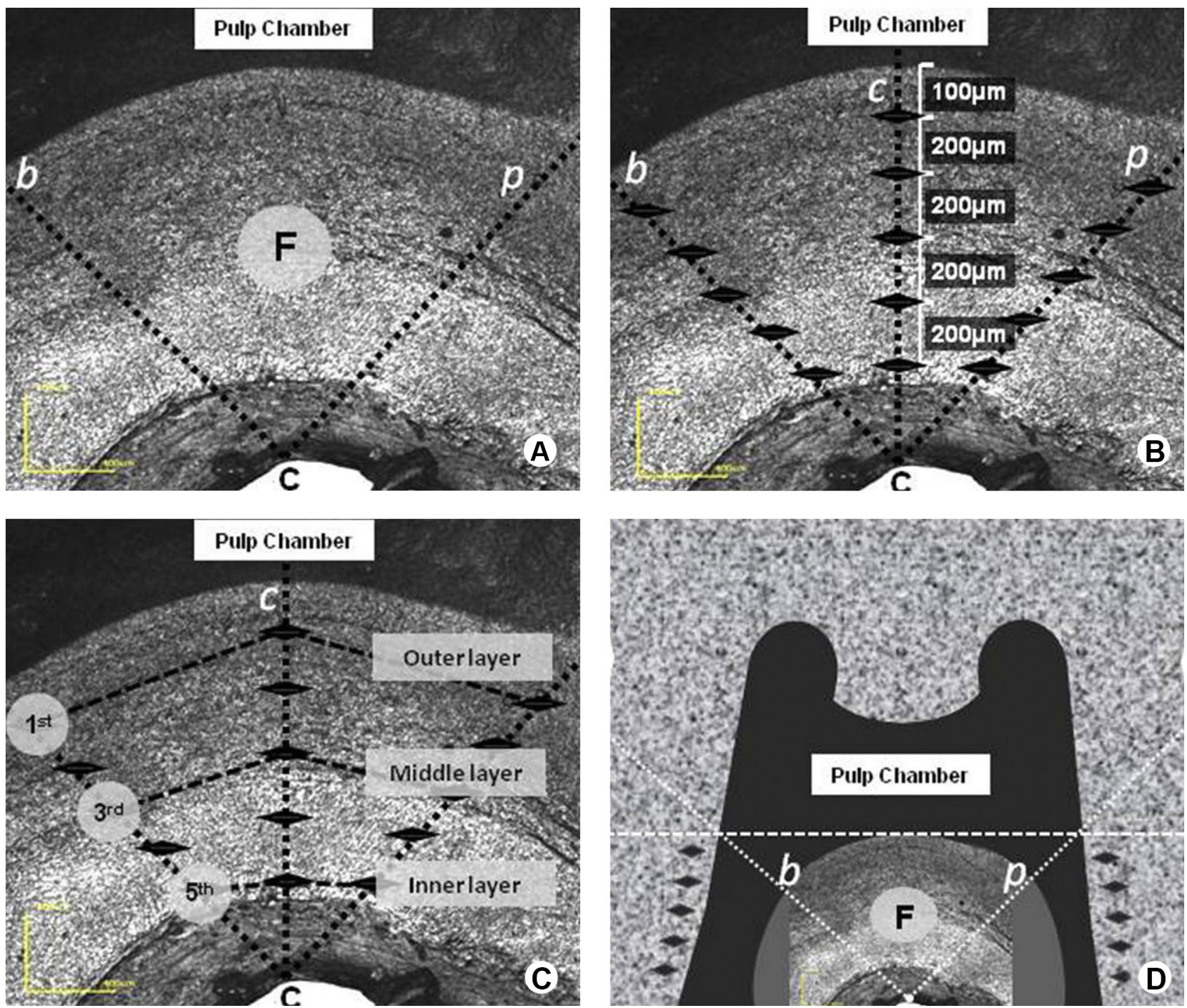

Figure 1. Schematic representation of the furcation and adjacent areas. A: delimitation of the furcation area $(\mathrm{F})$ and determination of the point on the outer surface of the most concave furcation portion (C). B: delimitation of the orthogonal lines of microhardness, buccal (b), central (c), and palatal (p), with preset distances between the indentations. C: Determination of the outer, middle and inner layers referenced by the first ( $1^{\text {st }}$ ), third $\left(3^{\text {rd }}\right)$, and fifth $\left(5^{\text {th }}\right)$ indentations of each region. D: Outline of the imaginary line at the entrance of the buccal and palatal canals to determine the region adjacent to the furcation. 
pulp chamber floor. The area between the two straight lines was defined as the furcation area (F) (Fig. 1A).

For analysis of microhardness, a Knoop hardness device was used (Shimadzu HMV-2000, Shimadzu Corporation, Kyoto, Japan), adjusted with a $10 \mathrm{~g}$ load for $15 \mathrm{~s}$. The measurements were conducted in three regions of the furcation (buccal, central, and palatal) and in two areas adjacent to it. The first analyzed furcation area followed a trajectory parallel to the straight orthogonal lines traced next to the buccal portion (buccal region). The second followed the opposite straight orthogonal lines, along the palatal portion (palatal region), and the third followed a bisector between two straight lines (central region). Five indentations were obtained for each region, the first performed at $100 \mu \mathrm{m}$ from the pulp chamber floor and the others towards the outermost point of the furcation ("C" point), with a $200 \mu \mathrm{m}$ distance between them (Fig. 1B). The layers of furcation also measured the dentin microhardness. The portion of dentin located closest to the pulp chamber floor was called the outer layer. The portion of dentin closest to the " $\mathrm{C}$ " point was the inner layer, and the portion of dentin between the two was the middle layer. The microhardness of the outer layer was determined by the average of the first measurements of each region (buccal, central, and palatal). The average of the third and fifth measurements from each region determined the microhardness of the middle and inner layers, respectively (Fig. 1C).

The region adjacent to the furcation was considered the portion of dentin located buccal and palatal to the furcation, with their respective root canals. Thus, a line was traced by a scalpel blade, passing through the entrance of the buccal and palatal canals to the outer face of the root. For each adjacent area, five indentations with standard lengths of $200 \mu \mathrm{m}$ between them were obtained (Fig. 1D). The first was performed immediately and apically to the traced line, following the trajectory parallel to the root canal towards the middle third of the root. Data were analyzed statistically by one-way ANOVA and Tukey-Kramer multiple-comparison at a 5\% significance level, using SPSS 15.0 software.

\section{Morphological Study of the Furcation Area}

The furcation region of the hemisections intended for the morphological study was treated with $37 \%$ phosphoric acid for $1 \mathrm{~min}$. Following, the specimens were rinsed in running water for 2 min and dried in paper towels. A laser scanning confocal microscope (Lext OLS 4000 - Olympus, Santa Barbara, CA, USA) was used to observe, in variable magnifications $(216,430,1074$, and $2,130 x)$, the direction of dentinal tubules, as well as the characteristics of the tissue in the furcation area.

\section{Analysis of Dentin Permeability}

For this analysis were selected ten maxillary premolars with divergent roots. After surgical access, the specimens were instrumented by the ProTaper system until \#F3. The root canal was irrigated with $10 \mathrm{~mL}$ of $1 \%$ sodium hypochlorite at each instrument exchange and $30 \mathrm{~mL}$ distilled water in the final irrigation.

Similar to the procedure performed in the microhardness analysis, the teeth were sectioned transversely in the middle portion of the crown and in the cervical portion of the roots. The remaining tooth structure containing the furcation area was externally covered with a layer of cyanoacrylate and two more layers of colorless nail polish. The specimens were immersed in a container containing a 10\% copper sulphate solution and 25\% ammonium hydroxide for 30 min. During the first $5 \mathrm{~min}$, vacuum was applied to the container.

After drying with paper and absorbent paper points, the specimens were embedded in acrylic resin and taken to the cutting machine. Slices $200 \mu \mathrm{m}$ thick were obtained from the furcation area, with the most central cut selected for analysis. After the histological procedures required for cutting, it was mounted on the blade for dye penetration analysis. A transmitted-light microscope was employed (Axiostar Plus, Carl Zeiss, Göttingen, Germany), equipped with AxioVision software to obtain the images (50x and 100x) and the measurement of the stained and non-stained areas. The software delimited the stained and non-stained areas and provided the values of the respective areas in square millimeter $\left(\mathrm{mm}^{2}\right)$ and percentage (\%) (Table 1).

\section{Results}

There was no statistically significant difference $(p>0.05)$ between the values of dentin microhardness related to the buccal $(39.9 \pm 3.1)$, central $(39.5 \pm 4.4)$ and palatal areas $(39.7 \pm 5.0)$, as well as to the furcation regions and adjacent buccal (39.1 \pm 5.8$)$ and palatal $(39.7 \pm 5.8)$ analysis $(p>0.05)$. The Tukey-Kramer complementary test $(\alpha=0.05)$ demonstrated that the microhardness of the inner layer $(42.3 \pm 3.7)$ is similar to the middle layer $(39.8 \pm 3.9)$, which in turn is similar to the outer layer $(37.1 \pm 3.9)$. However, there was a significant difference in the mean values of microhardness between the inner and outer layers $(p<0.05)$, demonstrating a greater hardness of the inner layer.

Through the morphological study, it was possible to observe that the dentinal tubules, in direction of the pulp chamber floor towards the inner layer, initially have a sinuous trajectory, tending to interweave with each other as they approach the middle layer (Fig. 2A). In the outer layer, the dentin is quite tubular, with ample light and clearly visible microscopically (Fig. 2B1). In the middle layer, the 
amount of visible tubules is much smaller than in the outer, presenting a large amount of calcified tubules (Fig. 2B2). The tubular calcification increases sharply as it approaches the inner layer (Fig. 2B3). At the end of the middle layer and beginning of the inner, the calcification is complete. The dentin of the inner layer resembles a sclerotic dentin,
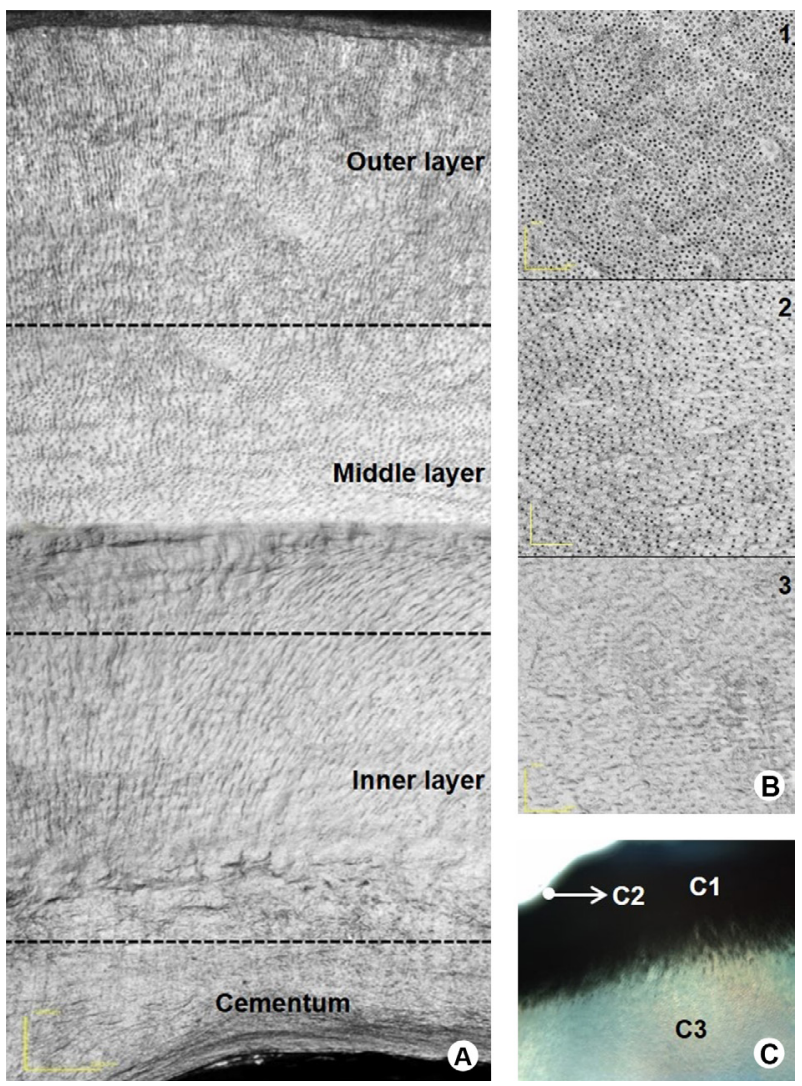

Figure 2. A: assembly of four photomicrographs (430x) of a single furcation with the hypothetical division of the outer, middle and inner layers, and the portion of cementum. B: photomicrographs (1074x) of the same specimen demonstrating the dentinal tubules of the outer (1), middle (2) and inner (3) layers. C: Partial histological image of the furcation (50x); $\mathrm{C} 1$ : area of stained dentin corresponding to the outer layer; C2: Pulp chamber floor; C3: area of non-stained dentin corresponding to the middle layer. with virtually no visible light (Fig. 2B3). The tissue in this region appears the as a compact mass that extends across the entire inner layer until it is limited by cement tissue at the root bifurcation (Fig. 2A).

The dentin permeability analysis of the ten histologically prepared specimens showed an average of $30.1 \pm 0.4 \mathrm{~mm}^{2}$ stained area and $8.92 \pm 1.5 \mathrm{~mm}^{2}$ of non-stained area. These values are equivalent to $12: 45 \pm 2.0 \%$ and $71.68 \pm 6.8 \%$ of the total area of the furcation, respectively. The histological images revealed that, in all specimens, the dye penetration area corresponded to the dentin layer located immediately underneath the pulp chamber floor (Fig. 2C). This dentin layer, in the present study, was named the outer layer. No specimens presented dye in the dentin portion corresponding to the inner layer.

\section{Discussion}

The analysis of dentin tissue hardness was performed in the three longitudinal axes of the furcation, here termed the buccal, central, and palatal regions and showed that there is a similarity of microhardness among them. The measurements were conducted from the pulp chamber floor towards the bifurcation of the root. In this way, the photomicrographs referring to the morphological study demonstrated sinuous and visible dentinal tubules, tending to an interweaving formation between themselves and to calcification. This dentin characteristic was observed, indistinctively, in the three regions. Similar findings were described by Cruz-Filho et al. (4) in relation to the dentin hardness of the mesial, middle and distal regions of the furcation in mandibular molars.

The dentin microhardness was also similar between the furcation regions and adjacent palatal and buccal. This finding may be related to the dentin portion from where the measurements were taken. The indentations in the adjacent regions occurred in the cervical third of the root, in the middle portion of the dentin between the cementum and the root canal. In this region, the dentin

Table 1. Original data, in $\mathrm{mm} 2$ and percentage (\%), of the stained and non-stained dentin areas, expressed as means and standard deviations

\begin{tabular}{cccccc}
\hline$(\mathrm{n})$ & Stained $\left(\mathrm{mm}^{2}\right)$ & Nonstained $\left(\mathrm{mm}^{2}\right)$ & Total $\left(\mathrm{mm}^{2}\right)$ & Stained $(\%)$ & Nonstained $(\%)$ \\
\hline 1 & 1.95 & 10.73 & 12.68 & 15.38 & 69.77 \\
2 & 1.95 & 10.83 & 12.78 & 15.26 & 70.98 \\
3 & 1.54 & 9.83 & 11.37 & 13.54 & 72.58 \\
4 & 5.51 & 6.04 & 8.77 & 62.79 \\
5 & 1.53 & 8.98 & 10.16 & 11.61 & 77.32 \\
6 & 1.18 & 8.01 & 9.04 & 11.39 & 70.30 \\
7 & 1.03 & 8.45 & 9.77 & 13.51 & 62.54 \\
8 & 1.32 & 8.15 & 10.18 & 11.70 & 79.65 \\
9 & 1.08 & 8.96 & 11.07 & 11.98 & 86.19 \\
10 & 1.22 & 9.81 & $49.7 \pm 6.5$ & $12.45 \pm 2.0$ & $71.68 \pm 6.8$ \\
Mean \pm SD & 1.26 & $8.92 \pm 1.5$ & & & \\
\hline
\end{tabular}


is not as hard as the dentin next to the cementum, nor as soft as the inner portion that lines the canal. In the cement-canal direction, the density of the tubules tends to increase, as well as in the apex-crown direction $(11,16,17)$, decreasing the microhardness of the tissue (18). A previous study (6) showed that the tubular density per $\mathrm{mm}^{2}$ on the inner surface of dentin of maxillary premolars is 44,000 in the wall of the pulp chamber, 38,000 in the cervical third, 20,000 in the middle and 19,000 in the apical third, with no significant difference between the density of the cervical and middle third.

When the dentin layers of furcation evaluated the microhardness, it was observed that the outer layer is significantly softer than the inner layer. Photomicrographs of the two areas showed that the dentin of the outer layer is more tubular, with ample and visible dentinal tubules, while the inner layer dentinal tubules are completely calcified. In the inner layer, the tissue resembles sclerotic dentin, looking like a compact dentin mass. Thus, the greater the number of dentinal tubules in a given area of dentin tissue, the lesser microhardness (19). It is important to emphasize that the smaller amount of dentinal tubules observed in the inner layer is mainly due to the calcification of the dentinal tubules. Calcification may occur because of external stimuli (20) or depending on the age of the patient (21). In the specific case of the inner layer of furcation, calcification may be related to another not yet known

湈 factor, probably associated with the process of dental furcation formation. Similar findings of the dentin tissue characteristics observed in this experiment were verified in two previous studies. The first study (4) reported that the dentin of the furcation of mandibular molars is quite mineralized, tending toward a greater calcification as it approaches the inner layer, with the latter layer being harder than the outer layer. The second study (5) found that after instrumentation of the mandibular molars, by different techniques, there was no penetration of copper ions through the dentinal tubules along the furcation. The permeability was only observed in the region close to the pulp chamber floor, since the furcation of these teeth is composed of amorphous dentin and less tubular than normal, especially near the bifurcation. Confirming this finding, histological analysis performed in this study showed that after biomechanics, the dye leakage was restricted to the dentin range belonging to the outer layer of the furcation, where the dentin is quite tubular. In spite of the previously reported dentin characteristics, Zaparolli et al. (22) found that the use of EDTA with or without sodium hypochlorite solution significantly reduces the dentin microhardness of the mandibular molars furcation. The penetration of irrigant solutions through dentinal tubules has already been detected at a distance of up to
$1,500 \mu \mathrm{m}$ from the root canal lumen $(23,24)$. However, in the furcation region of premolars, the irrigant solution must penetrate and act, probably only in the outer layer of dentin and at most, in the beginning of the middle. In the present study, the stained dentin portion was equivalent to approximately $12.5 \%$ of the total area of the furcation. By light microscopy, it was found that this permeable dentin portion corresponded essentially to the outer layer of the furcation. Thus, the authors' belief that the sodium hypochlorite used during biomechanical preparation as well as the chelating agents and canal medications do not diffuse through the dentinal tubules to the point of reaching the periapical tissues. Likewise, in vital teeth, calcification of dentinal tubules of the inner layer, with consequent lack of permeability in this region, could act as a natural barrier preventing the contact of the pulp with possible pathological agents in the periapex .

The analysis of permeability and the observation of morphological characteristics of furcation performed in this study suggest that this region presents greater difficulty for the penetration of fluids and quite possibly, of bacteria via the periodontium.

Despite the limitations of an in vitro study, it may be concluded that the dentin of furcation region in premolars is quite hard around the root bifurcation, with prevalence of fully calcified tubules in this region. Permeability occurs primarily in the dentin layer immediately underneath the pulp chamber where the dentin has a very tubular and softer structure.

\section{Resumo}

Estudou-se a morfologia, microdureza e permeabilidade dentinária da furca de pré-molares superiores. Dez pré-molares tiveram a porção oclusal da coroa e os terços radiculares médio e apical removidos. Cortou-se longitudinalmente o remanescente e delimitou-se a furca. As hemi-secções foram distribuídas em dois grupos. Num $(n=10)$, mediu-se a microdureza nas regiões vestibular, central e palatina, nas camadas externa, média e interna e nas porções vestibular e palatina adjacentes à furca. Utilizou-se dureza Knoop, carga de $10 \mathrm{~g}$ por 15 s. Os dados foram analisados pelo teste ANOVA e Tukey-Kramer $(\alpha=0.05)$. No outro grupo $(n=10)$ utilizou-se microscopia confocal para estudo da morfologia da dentina. Outros 10 espécimes foram instrumentados com Protaper e $\mathrm{NaOCl}$ a $1 \%$ e imersos em sulfato de cobre a $10 \%$ para análise da permeabilidade. Após preparo histológico os espécimes foram analisados em fotomicroscópio. Não houve diferença significante $(p>0,05)$ entre a microdureza das regiões vestibular $(39,9 \pm 3,1)$, central $(39,5 \pm 4,4)$ e palatina $(39,7 \pm 5,0)$, nem entre essas regiões e as adjacentes vestibular $(39,1 \pm 5,8)$ e palatina $(39,7 \pm 5,8)(p>0,05)$. A camada interna $(42,3 \pm 3,7)$ é mais dura que a externa $(37,1 \pm 3,9)(p<0,05)$. Há uma tendência dos canalículos calcificarem no sentido da camada externa para a interna. A porcentagem de área corada foi de $12,45 \pm 2.0$ e restrita à camada externa. As regiões vestibular, central e palatina da furca, bem como as adjacentes vestibular e palatina apresentaram microdureza semelhante entre si. A camada interna apresentou-se mais dura que a externa. Os canaliculos dentinários eram sinuosos e se entrelaçaram em direção à camada média. $A$ penetração de corantes se restringiu à camada externa.

\section{Acknowledgements}

This study was supported by the Brazilian Ageny CAPES - National Council for the Improvement of Higher Education. 


\section{References}

1. Ribeiro RG, Marchesan MA, Silva RG, Sousa Neto MD, Pécora JD. Dentin permeability of the apical third in different groups of teeth. Braz Dent J 2010;21:216-219.

2. Lo Giudice G, Cutroneo G, Centofanti A, Artemisia A, Bramanti E, Militi $A$, et al.. Dentin morphology of root canal surface: a quantitative evaluation based on a scanning electronic microscopy study. Bio Med Res Int 2015;2015:164065,7p.

3. Bureau of Library and Indexing Service. A study of terms; the concept "bifurcation". J Am Dent Assoc 1950;41:250-252.

4. Cruz-Filho AM, Flamini LES, Pécora JD. Morphology and microhardness of dentin at the furcation area of mandibular molars. J Endod 2014;40:129-132.

5. Pécora JD, Costa WF, Maia Campos G. A study of the dentinal permeability of the pulp chamber floor of human lower molars with separate roots. Braz Dent J 1990;1:17-24.

6. Ponce EH, Sahli CC, Fernandez JAV. Study of dentinal tubule architecture of permanent upper premolars: evaluation by SEM. Aust Endod J 2001;27:66-72.

7. Aubin JE. New immunological approaches to studying the odontoblast. J Dent Res 1985;64:515-522.

8. Hals E. Polarized light study of giant tubules in human and red deer coronal dentin. Scand J Dent Res 1983;91:105-111.

9. Kaye $H$, Herold RC. Phase contrast, polarization, interference and bright field microscopic observations on the lateral branch system. Arch Oral Biol 1966;11:355-368.

10. Schroeder L, Frank RM. High-resolution transmission electron microscopy of adult human peritubular dentine. Cell Tiss Res 1985;242:449-451.

11. Mjör IA, Shackleford JM. Microradiography of human pulp tissue and decalcified coronal dentine. Arch Oral Biol 1966;11:1307-1316.

12. Rapp $R$, Matthews $G$, Simpson $M$, Pashley $D H$. In vitro permeability of furcation dentin in permanent teeth. J Endod 1992;18:444-447.

13. Mello I, Coil J, Antoniazzi JH. Does a final rinse to remove smear layer interfere on dentin permeability of root canals? Oral Surg Oral Med Oral Pathol Oral Radiol Endod 2009;107:47-51.

14. Ordinola-Zapata R, Bramante CM, Graeff MS, del Carpio Perochena A, Vivan RR, Camargo EJ, et al.. Depth and percentage of penetration of endodontic sealers into dentinal tubules after root canal obturation using a lateral compaction technique: a confocal laser scanning microscopy study. Oral Surg Oral Med Oral Pathol Oral Radiol Endod 2009;108:450-457.
15. Wang Z, Shen Y, Haapasalo M. Effectiveness of endodontic disinfecting solutions against young and old Enterococcus faecalis biofilms in dentin canals. J Endod 2012;38:1376-1379.

16. Burrow MF, Takakura $H$, Nakajima M, Inai N, Tagami J, Takatsu T. The influence of age and depth of dentin on bonding. Dent Mat 1994;10:241-246.

17. Torabinejad M, Handysides $R$, Khademi AA, Bakland IK. Clinical implications of the smear layer in Endodontics: a review. Oral Surg Oral Med Oral Pathol Oral Radiol Endod 2002;94:658-666.

18. Pashley DH, Livingston MJ. Effect of molecular size on permeability coefficients in human dentine. Arch Oral Biol 1978;23:391-395

19. Pashley DH. Dentin predentin complex and its permeability: Physiologic overview. J Dent Res 1985;64:613-620.

20. Mjör IA. Effects of operative procedures on the dentin and the pulpdentin interface. Proceedings of Symposium on Dental Pulp 1982, pp. 32-52, Michigan School of Dentistry, Ann Arbor, MI, USA.

21. Whittaker DK, Kneale MJ. The dentine-predentine interface in human teeth. A scanning electron microscopy study. Br Dent J 1979;146:4346.

22. Zaparolli D, Saquy PC, Cruz-Filho AM. Effect of sodium hypochlorite and EDTA irrigation, individually and in alternation, on dentin microhardness at the furcation area of mandibular molars. Braz Dent J 2012;23:654-658.

23. Slutzky-Goldberg I, Maree M, Liberman R, Heling I. Effect of sodium hypochlorite on dentin microhardness. J Endod 2004;30:880-882.

24. Oliveira LD, Carvalho CAT, Nunes W, Valera MC, Camargo CHR, Jorge AOC. Effects of chlorhexidine and sodium hypochlorite on the microhardness of root canal dentin Oral Surg Oral Med Oral Pathol Oral Radiol Endod 2007;104:125-128.

Received March 30, 2016 Accepted September 13, 2016 